\title{
Przemyslaw Seruga
}

Uniwersytet Ekonomiczny we Wrocławiu

e-mail: przemyslaw.seruga@ue.wroc.pl

\section{ZAGROŻENIA W PROPONOWANYCH ZMIANACH PRAWNYCH DLA BIOLOGICZNEGO PRZETWARZANIA ODPADÓW}

\begin{abstract}
Streszczenie: Podjęte przez Polskę, wraz z jej wejściem do Unii Europejskiej (w 2004 r.), zobowiązania, dotyczące zapewnienia zredukowania masy odpadów komunalnych biodegradowalnych przeznaczonych do składowania o 35\% do 16 lipca 2020 r. (w stosunku do ilości biodegradowalnych odpadów wytworzonych w 1995 r.), wymagały rozwinięcia mechaniczno-biologicznego przetwarzania zmieszanych odpadów komunalnych (MBP). Jednak dopiero 11 września 2012 r. minister środowiska określił wymagania prawne odnośnie do MBP w Rozporządzeniu (Dz. U. 2012, poz. 1052). Aktualnie do konsultacji społecznych trafił projekt nowego rozporządzenia, które powinno wejść w życie z dniem 23 stycznia 2015 r., zastępując poprzednie, tracące moc z 22 stycznia 2015 r. Celem niniejszej pracy jest przedstawienie skutków proponowanych zmian uwarunkowań prawnych $\mathrm{z}$ punktu widzenia technologicznej realizacji biologicznego przetwarzania frakcji podsitowej ze zmieszanych odpadów komunalnych. Na podstawie analiz założeń technologicznych zrealizowanych i będących $w$ trakcie realizacji projektów instalacji w jednej z regionalnych instalacji przetwarzania odpadów komunalnych w Polsce oraz ich porównania z propozycjami nowych uregulowań prawnych podjęto próbę określenia zagrożeń dla MBP. Przeprowadzone badania skutkowały znalezieniem nieścisłości w uregulowaniach, mogących utrudniać przetwarzanie odpadów. W przypadku przetwarzania biologicznego, zwłaszcza beztlenowego, zapisy w aktualnym kształcie mogą wręcz uniemożliwić wytwarzanie biogazu. Stwierdzono również, że akty prawne dotyczące możliwości zagospodarowania powstającego stabilizatu oraz kontrola skuteczności procesu wymagają doprecyzowania.
\end{abstract}

Słowa kluczowe: odpady komunalne, biologiczne przetwarzanie, zmiany prawne.

DOI: $10.15611 /$ nit.2014.2.09

\section{Wstęp}

Przystępując w 2004 r. do Unii Europejskiej, Polska zobowiązała się, zgodnie z art. 5 Dyrektywy Rady 1999/31/WE z 26 kwietnia 1999 r. w sprawie składowania odpadów (Dz. Urz. WE L182 z 16.07.1999 r.), do osiągnięcia założonych poziomów redukcji składowania odpadów komunalnych ulegających biodegradacji. Korzystając z 4-letniego okresu przejściowego, do 2020 roku państwo polskie musi zapewnić 
zmniejszenie masy bioodpadów kierowanych na składowiska do 35\% w stosunku do ilości zdeponowanych w 1995 r. [Dyrektywy Rady z 26 kwietnia 1999 r ....].

Mając na uwadze przyjęte zobowiązania, konieczna okazała się intensyfikacja działań ustawodawczych dotyczących systemu gospodarki odpadami. Głównym aktem prawnym w tej kwestii jest Ustawa o odpadach z dnia 14 grudnia 2012 r. (Dz. U. 2013, poz. 21), która określa środki służące ochronie środowiska, życia i zdrowia ludzi, zapobiegające i zmniejszające negatywny wpływ na środowisko oraz zdrowie ludzi wynikający z wytwarzania odpadów i gospodarowania nimi oraz ograniczające skutki użytkowania zasobów i poprawiające efektywność takiego użytkowania [Ustawa z dnia 14 grudnia 2012 r. ...].

Kolejnym ważnym aktem prawnym jest znowelizowana Ustawa o utrzymaniu czystości i porządku w gminach z dnia 19 września 1996 r. (Dz. U. 2012, poz. 391). Z jej zapisów wynika, że po 1 lipca 2013 r. gminy są „,właścicielami” odpadów i to na nich spoczywa obowiązek zbierania odpadów oraz prowadzenia regionalnych instalacji do przetwarzania odpadów komunalnych (RIPOK). Tym samych na tym szczeblu administracji spoczęła odpowiedzialność za realizację wspomnianych zobowiązań wobec Wspólnoty Europejskiej [Ustawa z dnia 13 września 1996 r. ...].

Aktem wykonawczym, który wymusza konieczność wprowadzenia zmian w zagospodarowywaniu odpadów, jest Rozporządzenie Ministra Gospodarki z 7 września 2005 r. w sprawie kryteriów oraz procedur dopuszczania odpadów do składowania na składowisku danego typu (Dz. U. 2005 nr 186, poz. 1553 z późn. zm.). Zgodnie z jego zapisami od 1 stycznia 2013 r. obowiązują, wcześniej niestosowane, kryteria dopuszczające odpady do składowania. Dla odpadów komunalnych ustalone zostały wartości graniczne takich parametrów, jak:

- zawartość całkowitego węgla organicznego (TOC): 5\% s.m.,

- straty przy prażeniu (LOI): $8 \%$ s.m.,

- ciepło spalania: $6 \mathrm{MJ} / \mathrm{kg}$ s.m.

Ich przekroczenie oznacza, że odpady nie mogą być zdeponowane na składowiskach odpadów innych niż niebezpieczne i obojętne [Rozporządzenie Ministra Gospodarki z 7 września 2005 r. ...].

Ustalanie wymienionych wartości granicznych w zasadzie uniemożliwia składowanie odpadów komunalnych bez ich wcześniejszego przetworzenia. Wymusiło to na prawodawcach ustanowienie standardu zarówno w zakresie przeróbki odpadów komunalnych, jak i badania produktów po tym procesie. Wymagania te zostały określone w Rozporządzeniu Ministra Środowiska z 11 września 2012 r. w sprawie mechaniczno-biologicznego przetwarzania zmieszanych odpadów komunalnych (Dz.U. 2012, poz. 1052). Zgodnie z tym aktem wykonawczym mechaniczno-biologiczne przetwarzanie odpadów komunalnych składa się z procesów mechanicznego i biologicznego przetwarzania odpadów, połączonych $\mathrm{w}$ jeden integralny proces technologiczny, ukierunkowany na przygotowanie do procesów odzysku, w tym recyklingu, odzysku energii, termicznego przekształcania albo składowania [Rozporządzenie Ministra Środowiska z 11 września 2012 r. ...]. 
Wspomniany akt prawny traci moc 22 stycznia 2015 r. W związku z tym do konsultacji społecznych trafił projekt nowego rozporządzenia odnośnie do MBP, które powinno wejść w życie z dniem 23 stycznia 2015 r.

Według obu wspomnianych dokumentów pierwszy etap obróbki odpadów, mechaniczne przetwarzanie, ma na celu wydzielenie określonych frakcji dających się wykorzystać materiałowo lub energetycznie oraz frakcji, które wymagają dalszych procesów stabilizacji biologicznej. Zgodnie z rozporządzeniem dalszego biologicznego przetworzenia wymaga frakcja o wielkości co najmniej 0-80 mm, oznaczona kodem ex 191212.

Celem niniejszej pracy jest przedstawienie potencjalnych skutków proponowanych zmian uwarunkowań prawnych dla realizacji biologicznego przetwarzania frakcji 0-80 mm wydzielonej ze zmieszanych odpadów komunalnych na podstawie analiz założeń technologicznych zrealizowanych i będących $w$ trakcie realizacji projektów instalacji w jednej z regionalnych instalacji przetwarzania odpadów komunalnych w Polsce.

\section{Analiza skutków proponowanych zmian prawnych}

Opierając się na obowiązujących przepisach prawnych i wykorzystując środki z Funduszy Europejskich, wiele zakładów zajmujących się gospodarowaniem odpadami zainwestowało $\mathrm{w}$ projekty mające się przyczynić do osiągnięcia założonych poziomów redukcji deponowania odpadów. Zmiany wymagań na gruncie prawnym mogą spowodować trudności z wykorzystaniem realizowanych inwestycji.

Zgodnie z $§ 4$ ust. 1 i 2 projektu nowego rozporządzenia, które stanowią odpowiednio, że: „Frakcja podsitowa wymaga zastosowania procesów biologicznego przetwarzania, przez które rozumie się procesy prowadzone w warunkach tlenowych lub beztlenowych z udziałem mikroorganizmów, w wyniku których następują zmiany właściwości fizycznych, chemicznych lub biologicznych odpadów", a także: „W procesach, o których mowa w ust. 1, przetwarza się wyłącznie odpady frakcji podsitowej wytworzone w części mechanicznej tej samej instalacji. Odpady frakcji podsitowej nie mogą być mieszane z innymi rodzajami odpadów, w tym w szczególności z odpadami zbieranymi w sposób selektywny, oraz odpadami wytworzonymi w innej instalacji”.

W związku z tym, że aktualnie wykorzystywane technologie w procesach fermentacji preferują wielkość dostarczanego podsitowia frakcji 0-60 mm (lub 20-60 mm), w celu spełnienia warunków rozporządzenia należałoby z frakcji nadsitowej pozostały balast, przewidziany do składowania, albo przesiać i wydzielić frakcję 60-80 mm i ją skierować do przetworzenia biologicznego lub cały balast skierować do przetworzenia biologicznego.

Do procesów fermentacji, w celu poprawienia jakości i ilości wytwarzanego biogazu, przewidziany jest wsad, który zawierać w sobie będzie frakcję podsitową, a także (jeśli będzie taka potrzeba) część selektywnie zebranych odpadów zielonych, 
odpadów kuchennych (np. z gastronomii), z przemysłu rolno-spożywczego (np. tłuszczy), nieprzefermentowanych osadów ściekowych, a także materiału strukturyzującego w postaci zrębków drzewnych. Omawiany w rozporządzeniu zapis uniemożliwia dodatnie do fermentacji innych odpadów niż frakcja podsitowa. Również w przypadku procesów kompostowania może wystąpić konieczność dodawania selektywnie dostarczonych odpadów strukturalnych (rozdrobnionych gałęzi itp.) lub osadów ściekowych w celu poprawy wilgotności czy zasobności w przyswajalne substancje organiczne, aby umożliwić prawidłowe prowadzenie procesu biologicznego.

$\mathrm{Z}$ kolei $\S 4$ ust. 3 oraz $\S 4$ ust. 4 omawianego rozporządzenia określają wymagania dla procesów biologicznych i nakazują, że proces tlenowego i beztlenowego przetwarzania całej frakcji podsitowej należy prowadzić dwustopniowo.

Nakaz biologicznej obróbki całej frakcji 0-80 mm, bez możliwości uprzedniego odsiania z niej frakcji drobnej (tj. 0-20 mm), może powodować zakłócenia prawidłowego przebiegu procesu stabilizacji w warunkach beztlenowych, tj. pojawienie się zjawiska sedymentacji składników mineralnych zawartych w drobnej frakcji tworzących na dnie reaktora zwartą, trudną do przemieszczania warstwę, powodującą dodatkowo szybsze zużycie elementów mechanicznych przemieszczających i mieszających wsad w fermentatorze lub nawet ich stałe blokowanie. Frakcja drobna 0-20 mm byłaby mieszana $\mathrm{z}$ fermentatem $\mathrm{i}$ podawana do przetwarzania $\mathrm{w}$ warunkach tlenowych.

Fermentacji poddawana byłaby tylko frakcja 0-60 mm lub nawet $15-60 \mathrm{~mm}$, więc de facto tylko ona będzie przetwarzana dwustopniowo.

W wyniku procesów biologicznych nastąpi zmiana kodu odpadów z ex 191212 na 1905 99, produkt zwany stabilizatem. Zgodnie z $§ 4$ ust. 7: „Stabilizat, po przesianiu na sicie o prześwicie oczek o wielkości do $20 \mathrm{~mm}$, może być stosowany do odzysku wyłącznie przy zamknięciu składowiska jako odpad o kodzie ex 1905 99, zgodnie z wymaganiami określonymi w rozporządzeniu wydanym na podstawie art. 124 ust. 6 ustawy z dnia 14 grudnia 2012 roku o odpadach".

Brak możliwości odzysku materiału nadającego się zarówno na warstwę izolacyjną, jak i na okrywę biologiczną w ramach rekultywacji bieżącej, a także do procesu R10. Zamknięcie składowiska może się odbywać teraz np. co 10 lat, czyli w tym okresie nie będzie można prowadzić żadnego procesu odzysku.

Brak możliwości wytwarzania ze stabilizatu 190599 kompostu nie odpowiadającego wymaganiom (co jest dopuszczalne w aktualnie obowiązującym rozporządzeniu - kod odpadu: 1905 03) może powodować dodatkowe koszty i obciążenie środowiska naturalnego. Problematyczna może się również okazać prawidłowa, zgodna z wymaganiami prawnymi kontrola parametrów procesu.

W paragrafie 6 ust. 1 omawianego rozporządzenia wymagania dla stabilizatu po biologicznym przetwarzaniu: „Proces biologicznego przetwarzania odpadów (...), powinien być prowadzony w taki sposób, aby uzyskany stabilizat osiągnął wartość AT4 poniżej $10 \mathrm{mg} \mathrm{O}_{2} / \mathrm{g}$ suchej masy oraz spełniał jedno z następujących wymagań:

- straty prażenia stabilizatu będą mniejsze niż 35\%, a zawartość węgla organicznego mniejsza niż $20 \%$ suchej masy, lub 
- ubytek masy organicznej w stabilizacie w stosunku do masy organicznej w odpadach, mierzony stratą prażenia lub zawartością węgla organicznego jest większy niż 40\%".

O ile parametr AT4 (aktywność oddychania; parametr wyrażający zapotrzebowanie tlenu przez próbkę odpadów w ciągu 4 dni, $\mathrm{mg} \mathrm{O}_{2} / \mathrm{g}$ s.m.) odnosi się do odpadów ulegających biodegradacji zawartych w frakcji podsitowej kierowanej do biologicznej stabilizacji, o tyle na dwa pozostałe parametry wpływ będą miały zawartość tworzyw sztucznych, metali oraz minerałów, co w przypadku frakcji podsitowej z odpadów zmieszanych jest normą. Tymczasem w zasadzie tylko wynik AT4 daje pełny obraz, co się stało z frakcją biodegradowalną, tj. czy jej podatność na rozkład została mocno zredukowana. Pozostałe dwa parametry dadzą zafałszowany obraz procesu, nie wspominając o wzroście kosztów eksploatacji czy zwiększeniu potrzeby wykonywania dodatkowych badań.

Z kolei według $\S 7$ ust. 3 wspomnianego rozporządzenia „Próbki pobiera się po procesie biologicznego przetwarzania odpadów (...) z każdej partii, która zostanie wytworzona w jednym pełnym cyklu, do czasu spełnienia wymagań określonych dla stabilizatu w $\S 6$ ust. 1". Dla procesów statycznych (tj. prowadzonych w reaktorach i kontenerach) dotyczy to każdego wsadu, dla procesów ciągłych, w szczególności procesu fermentacji, brak jest odniesienia. Powoduje to wzrost kosztów dla jednych typów technologii oraz problemy interpretacyjne dla innych.

\section{Zakończenie}

Przeprowadzone analizy aktów prawnych skutkowały znalezieniem nieścisłości w projekcie nowych uregulowań dotyczących mechaniczno-biologicznego przetwarzania odpadów. Mogą one wpłynąć na skuteczność wykorzystania projektów inwestycyjnych. W przypadku procesów biologicznych, zwłaszcza beztlenowych, zapisy prawne w proponowanym kształcie mogą wręcz uniemożliwić wytwarzanie biogazu wskutek zakazu dodawania materiałach strukturyzujących. Z kolei wydzielenie inertów, związane z koniecznością dwustopniowej stabilizacji całej frakcji, może doprowadzić do uszkodzeń instalacji technicznych. Omawiany akt prawny w zapisach dotyczących możliwości zagospodarowania powstającego stabilizatu oraz kontrola skuteczności procesu również wymagają doprecyzowania.

\section{Literatura}

Dyrektywy Rady 1999/31/WE z 26 kwietnia 1999 r. w sprawie składowania odpadów, Dz. Urz. WE L182 z 16.07.1999 r.

Rozporządzenie Ministra Gospodarki z 7 września 2005 r. w sprawie kryteriów oraz procedur dopuszczania odpadów do składowania na składowisku danego typu, Dz. U. 2005 nr 186, poz. 1553 z późn. zm. 
Rozporządzenie Ministra Środowiska z 11 września 2012 r. w sprawie mechaniczno-biologicznego przetwarzania zmieszanych odpadów komunalnych, Dz. U. 2012, poz. 1052.

Ustawa z dnia 13 września 1996 r. o utrzymaniu czystości i porządku w gminach, Dz. U. 2012, poz. 391 .

Ustawa z dnia 14 grudnia 2012 r. o odpadach, Dz. U. 2013, poz. 21.

\title{
THREATS FOR BIOLOGICAL TREATMENT OF MUNICIPAL WASTES DUE TO LAW REGULATION CHANGES PROPOSAL
}

\begin{abstract}
Summary: Joining the European Union in 2004 Poland has been obligated to reduce the weight of biodegradable municipal waste to be landfilled by $35 \%$ to 16 July 2020 (relative to the amount of biodegradable waste produced in 1995). These actions required the development of mechanical-biological treatment of mixed municipal wastes (MBT). However, the Minister of the Environment described the legal requirements relating to MBT in September 2012. Currently, a draft of new regulation, which should enter 23 January 2015, was given for public consultation. The aim of this study is to present the effects of proposed law regulation changes on the realization of the biological treatment of the municipal wastes from the technological point of view. Based on the analysis of the technology already implemented and pending projects in one of the Regional Municipal Waste Processing Plants in Poland and their comparison with the proposals of new law regulations, an attempt to identify threats to MBT was taken. The conducted analyzes resulted in finding inconsistencies in regulations that may hinder the municipal wastes treatment. In the case of biological, especially anaerobic treatment, changes in present form may even stop the production of biogas. It was also found that regulations about possibilities of using products of aerobic treatment as well as control of the process needed to be clarified.
\end{abstract}

Keywords: municipal wastes, biological treatment, law regulations. 